\title{
Cryptosporidium parvum transport from cattle fecal deposits on California rangelands
}

\author{
KENNETH W. TATE, EDWARD R. ATWILL, MELVIN R. GEORGE, NEIL K. MCDOUGALD, AND ROYCE E. \\ LARSEN
}

Authors are rangeland watershed specialist, Agronomy and Range Science, University of California, Davis, Calif. 95616-8515; environmental health spe cialist, School of Veterinary Medicine, University of California, Veterinary Medicine Teaching and Research Center, Tulare, Calif. 93274; range and pasture specialist, Agronomy and Range Science, University of California, Davis, Calif. 95616-8515; natural resources and livestock advisor, University of California Cooperative Extension, Madera, Calif. 93637; and watershed advisor, University of California Cooperative Extension, San Luis Obispo, Calif. 93446.

\section{Abstract}

Cryptosporidium parvum is a fecal borne protozoan parasite that can be carried by and cause gastrointestinal illness in humans, cattle, and wildlife. The illness, cryptosporidiosis, can be fatal to persons with compromised immune systems. At question is the potential for $C$. parvum in cattle fecal deposits on rangeland watersheds to contaminate surface water. First, $C$. parvum oocysts must be released from fecal deposits during rainfall, becoming available for transport. In 1996, we examined the transport of $C$. parvum oocysts in overland flow from fecal deposits under natural rainfall and rangeland conditions at the San Joaquin Experimental Range in Madera County, Calif. Our null hypothesis was that $C$. parvum oocysts are not released from fecal pats and transported $1 \mathrm{~m}$ downslope as overland flow with rainfall. Paired plots were located on 10, 20, and 30\% slope sites. Each plot was loaded with four, $200 \mathrm{~g}$ fecal pats dosed with $10^{5}$ oocysts $\mathrm{g}^{-1}$. Pats were placed $1.0 \mathrm{~m}$ above the base of each plot. Composite runoff samples from each plot were analyzed for oocyst concentration following each of 4 storm events. Oocysts were transported during each storm. Slope was a significant factor in oocyst transport, with oocyst transport increasing with slope. Although not significant, there was an apparent flushing effect of oocysts across storms, with the majority transported in the first 2 storms. A pilot rainfall simulation experiment also revealed a flushing phenomenon from pats during individual rainfall events. $C$. parvum oocysts in fecal pats on rangeland can be transported from fecal deposits during rainfall events, becoming available for transport to water-bodies. Future studies need to examine surface and subsurface transport of oocysts on rangeland hillslopes for distances greater than $1 \mathrm{~m}$.

Key Words: pathogens, water quality, fate and transport, buffer strip

Cryptosporidium parvum (Tyzzer 1912), a fecal-oral protozoan parasite, is an important etiologic agent of enterocolitis in mammals. C. parvum appears to be infectious for and is shed by humans, domestic animals, and wildlife species (Casemore et al. 1997). Waterborne transmission to humans has emerged as a leading public health problem here and abroad (MacKenzie et al.

Research was funded by UC Division of Agriculture and Natural Resources 1995-96 Competitive Grants Program Grant \#020.

Manuscript accepted 17 Aug. 1999.
Resumen

Cryptosporidium parvum es un protozoario parásito que se transporta en las heces fecales y que puede ser acarreado por humanos, bovinos y fauna silvestre a los que puede causar enfermedades gastrointestinales. La enfermedad cryptosporidiosis puede ser fatal para personas con un sistema inmunológico débil. Se cuestiona el potencial del $C$. parvum contenido en las heces fecales de bovinos depositadas en las cuencas hidrológicas de pastizal para contaminar las aguas superficiales. Primero, los oocistos del $C$. parvum deben ser liberados de las heces fecales durante la ocurrencia de lluvias para estar disponibles para ser transportados. En 1996, en la Estación Experimental de Pastizales de San Joaquín en el condado de Madera, Calif., examinamos el transporte de oocistos de $C$. parvum en el flujo superficial proveniente de áreas con depósitos fecales bajo lluvia natural y en condiciones de pastizal. Nuestra hipótesis nula fue que los oocistos de $C$. parvum no son liberados de los depósitos fecales y transportados $1 \mathrm{~m}$ cuesta abajo como en el flujo superficial de la lluvia. Se localizaron parcelas apareadas en sitios con 10,20 y $30 \%$ de pendiente. En cada parcela se colocaron 4 depósitos fecales de $200 \mathrm{~g}$ de dosificados con 105 oocistos $\mathrm{g}^{-1}$, las heces fecales se colocaron $1 \mathrm{~m}$ arriba de la base de cada parcela. Se analizaron muestras compuestas del escurrimiento de cada parcela para determinar la concentración de oocistos después de cada uno de 4 eventos de lluvia. Los oocistos fueron transportados durante cada tormenta. La pendiente fue un factor significante en el transporte de oocistos, incrementandose el transporte al aumentar la pendiente. Aunque no significante, hubo un efecto aparente de lavado de los oocistos a través de las tormentas, en donde la mayoría de ellos se transportaron en las primeras 2 tormentas. Un experimento piloto con simulador de lluvia también revelo este fenómeno de lavado durante eventos individuales de lluvia. Los oocistos de $C$. parvum de heces fecales localizadas en pastizales pueden ser transportadas durante los eventos de lluvia, llegando a ser disponibles para su transporte a cuerpos de agua. Se necesitan estudios futuros para examinar el transporte superficial y subterráneo de oocistos en las montañas de pastizal a distancias mayores de $1 \mathrm{~m}$.

1994, LeChevallier and Norton 1995). Public health officials have considered cattle as possible sources of this parasite because of C. parvum infection within cattle populations (MacKenzie et al. 1994). In 1997, the City of San Francisco, Calif. proposed to terminate long-standing grazing leases and ban cattle from 12,000 
ha of rangeland it owns due to concerns about $C$. parvum from cattle grazing in watersheds providing drinking water (Stephens 1997). This proposal was dropped following development of a comprehensive water quality control plan for the watershed in question (Barry et al. 1998), but public and regulatory agency concerns about the link between grazing, water quality, and human health are still quite high. Normal drinking water treatment does not remove oocysts from source water, and alternative treatment methods are expensive.

For bovine-derived $C$. parvum to be a waterborne health risk, the infectious stage of the parasite (oocysts) must reach source water via direct deposition in water or via hydrologic transport from upland and riparian areas. Direct contamination of source water occurs when fecal material is deposited within a stream or its flood plain. Larsen et al. (1988) report that free ranging cattle in Oregon deposited $3.4 \%$ and $1.7 \%$ of their feces in a stream in August and November, respectively. In a system where the stream provided the only cattle drinking water, Gary et al. (1983) found that $6.7 \%$ to $10.5 \%$ of defecations by beef cattle were deposited directly into streams.

For cattle feces deposited in upland watershed areas to contaminate source water, oocysts must be transported from fecal pats during hydrological events such as rainfall or snowmelt. Under simulated irrigation, Mawdsley et al. (1996) observed overland and subsurface leaching transport of $C$. parvum oocysts from liquid manure slurries applied to tilted (7.5\%) soil boxes ( $80 \mathrm{~cm}$ long x $56 \mathrm{~cm}$ wide x $25 \mathrm{~cm}$ deep). The boxes were filled with poor draining silty clay loam soil and planted with perennial ryegrass. Transport of indicator bacteria from cattle fecal deposits under artificial rainfall and plot scenarios has been documented (Buckhouse and Gifford 1976, Thelin and Gifford 1983, Kress and Gifford 1984, and Larsen at al. 1994). Studying fecal coliform transport from cattle fecal pats, Larsen et al. (1994) report that on average $17 \%$ of fecal coliforms in the pats were transported from the pats during 0.5 hour simulated rainfall events. The authors report an average reduction of 83 and $95 \%$ of fecal coliforms in overland flow passing through grass turf at 1.37 and $2.13 \mathrm{~m}$ below the fecal pats, respectively. Kress and Gifford (1984) found that age of fecal deposit and recurrent rainfall both reduced fecal coliform release below that of new and once rained on deposits. Buckhouse and Gifford (1976) examined fecal and total coliform transport from 1 month old fecal deposits on rangeland in Utah under simulated rainfall. They report fecal coliform concentrations in overland flow of 75,000 bacteria $100 \mathrm{ml}^{-1}$ at $0 \mathrm{~m}$ from the pat, and 23 bacteria $100 \mathrm{ml}^{-1}$ at 1 $m$ from the pat..

The objective of this study was to document the transport of $C$. parvum oocysts from cattle fecal deposits on California rangelands under natural rainfall and hillslope conditions. Establishing this fact is the logical precursor to detailed experiments examining oocyst transport process es on rangeland hillslopes. Our null hypothesis was that $C$. parvum oocysts are not released from the fecal deposits and transported $1 \mathrm{~m}$ as overland flow during natural rainfall events. We selected this distance based upon the work of Larsen et al. (1994) and Buckhouse and Gifford (1976) which shows significant reduction in coliform transport as overland flow beyond $1 \mathrm{~m}$. Because land slope is an important factor controlling overland flow generation (Haan et al. 1994) and in determining the spatial distribution of cattle fecal deposition (Larsen 1989, Tate et al. 1998), we also examined the effect that percent slope had on the concentration of $C$. parvum oocysts in overland flow collected $1 \mathrm{~m}$ from fecal deposits.

\section{Methods}

\section{Study Site}

The study was conducted on the 1,772 ha San Joaquin Experimental Range (SJER) located in Madera County, Calif. The SJER is representative of grazed hardwood rangeland in central and southern Sierra Nevada west slope foothills, and is grazed year-long by a 210 cow, commercial type cow-calf herd. Elevation at SJER ranges from 213 to $518 \mathrm{~m}$. Climate is Mediterranean with an average annual precipitation of $485 \mathrm{~mm}$ falling almost entirely as rainfall November through May. Upland watershed areas are dominated by the coarse textured Ahwahnee soil series, a Mollic Haplustaif. Upland soil depth ranges from 0.2 to $0.6 \mathrm{~m}$, lain over weathered granitic parent material. Vegetation at SJER is oak woodland/savanna with annual grassland understory. Blue oak (Quercus douglasii Hook \& Arn.) and interior live oak (Quercus wislizenii A.DC.) dominate the overstory while wild oats (Avena fatua L.), rip-gut brome (Bromus diandrus Roth), soft chess (Bromus rubens L.), redstem filaree (Erodium cicutarium (L.) L'Her), and oth- ers dominate the annual grassland understory.

In 1994, three sets of paired overland flow plots (total 6 plots) were constructed on the upland Ahwahnee soil type. All plots were located within a 138 ha, grazed experimental watershed. Precipitation and streamfiow are automatically monitored on a 0.25 hour time step at the outlet of this watershed. Paired plots ( 2 replicates) were located on $10 \%, 20 \%$, and $30 \%$ slopes. A $1.0 \mathrm{~m}$ buffer was maintained between the 2 plots at each site. Each plot was $2 \mathrm{~m}$ wide (parallel to slope) by $22.1 \mathrm{~m}$ long (uphill-downhill). The upper and side boundaries of each plot were bordered with metal flashing inserted $15 \mathrm{~cm}$ into the soil to insure overland flow from adjacent areas did not flow into the plots. A collection system was installed at the bottom of each plot to allow for composite sampling of overland flow. The design did not allow for accurate measurement of total runoff volume from each plot. Plots were protected from grazing and cattle fecal deposition for a year prior to this study. All existing fecal deposits were removed from the plots 1 year prior to the experiment. Average soil characteristics for the 6 plots were; bulk density $=1.5 \mathrm{~g} \mathrm{~cm}^{-3}$, porosity $=$ $44.1 \%, \mathrm{pH}=6.5, \mathrm{EC}=0.58 \mathrm{mmhos} \mathrm{cm}^{-1}$, organic matter content $=1.11 \%$, total carbon $=1.15 \%$, cation exchange capacity $=$ $6.67 \mathrm{meq} 100 \mathrm{gm}^{-1}$, and percent sand/silt/clay $78 \% / 18 \% / 4 \%$. There were no trees on the plots, nor within $30 \mathrm{~m}$ of the plots. Herbaceous dry matter on the plots averaged $1,669 \mathrm{~kg} \mathrm{ha}^{-1}$ at $2 \mathrm{Feb}$. 1996.

\section{Treatments}

Two experiments were conducted in this study. For the first experiment, each of the 6 overland flow plots was loaded with four, $200 \mathrm{~g}$ fecal pats dosed with $1 \times 10^{5}$ C. parvum oocysts $\mathrm{g}^{-1}$. We used a concentration of $1 \times 10^{5} C$. parvum oocysts $\mathrm{g}^{-1}$ because this level represented a moderately high shedding intensity for calves. Concentrations of oocysts often exceed I X $10^{5}$ oocysts $\mathrm{g}^{-1}$ for both naturally and experimentally infected calves (Xiao and Herd 1994, Fayer et al. 1998). Pat size is representative of pats from calves less than 4 months old, the primary bovine source of $C$. parvum oocysts on California's rangelands (Atwill et al. 1999). The total amount of fecal material is representative of loading around feeding stations, water troughs, and other cattle concentration areas on rangeland (Hafez 1969, Larsen 1989 and Tate et al. 1998). Experimentally constructed fecal pats 
allow us to control the load of $C$. parvum oocysts on each plot. Source of fecal material for experimentally constructed fecal pats was fresh fecal material collected from cattle at the SJER and which tested negative for $C$. parvum based on immunofluorescent microscopy (MERIFLUOR Cryptosporidium/Giardia direct immunofluorescent detection kit, Meridian Diagnostics, Inc. Cincinnati, Ohio). Source of $C$. parvum oocysts for experimentally constructed fecal pats were from feces from naturally-infected dairy calves and were purified using a previously described technique (Arrowood and Sterling 1987). The concentration of purified oocysts was determined with a hemacytometer. Naturally-infected calves were from several commercial dairies located in Kings and Tulare counties, Calif.

On 2 February 1996, the 4 fecal pats were placed $1.0 \mathrm{~m}$ above the bottom of each plot. A composite overland flow sample was collected from each plot following 4 subsequent storm events during the remainder of the 1 October 1995 to 30 September 1996 water year. Runoff volume from each plot was not measured. Concentrations of oocysts were measured for each sample by adding $2.5 \mathrm{ml}$ of $10 \%$ Tween 80, 1Q\% SDS solution to $250 \mathrm{ml}$ aliquot of each sample, mixing $30 \mathrm{sec}-$ onds, then filtering through mesh size 40, 100 , and 200 sieves. The suspension was centrifuged, supernatant removed, and the pellet resuspended in 0.25 to $4 \mathrm{ml}$ of $0.2 \%$ Tween 20 in distilled water. Ten ul of suspension was dried onto a commercially prepared glass slide and the direct immunofluorescent assay performed according to the manufacturer's instructions (MERIFLUOR Cryptospori dium/Giardia direct immunofluorescent detection kit, Meridian Diagnostics, Inc. Cincinnati, Ohio). The total number of oocysts was enumerated for each sample and the concentration of oocysts for each water sample determined by adjusting for the estimated percent recovery of the immunofluorescent assay. An ANOVA with repeated measures (Dixon 1992) was used to determine significance, with slope (3 levels) as the fixed factor and sample date (4 storm events) as the repeated measure whereby the runoff from 6 plots ( 3 slopes x 2 replicates/slope) was sampled across 4 storms.

In the second experiment, we conducted a single artificial rainfall experiment to provide preliminary information for development of a future laboratory-based study of the transport of oocysts throughout a rainfall event. Due to natural plot variabil-

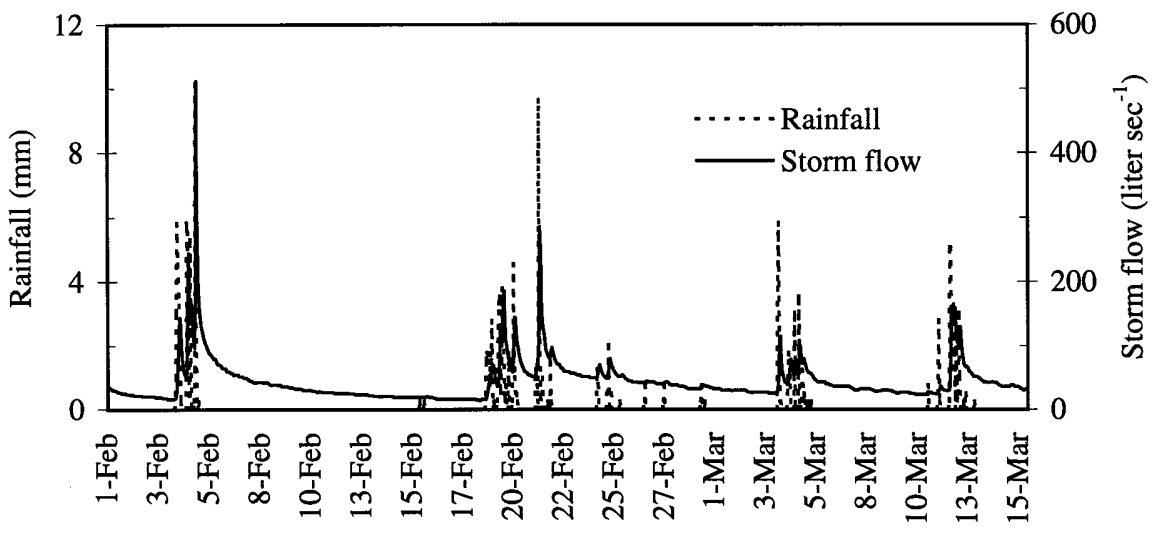

Fig. 1. Rainfall (mm) and storm flow (liter $\sec ^{-1}$ ) from the San Joaquin Experimental Range watershed during the study period.

ity, uncertain weather and flow, as well as logistics it is difficult to obtain this type of detailed time-dependent information inthe-field under natural rainfall scenarios. For this trial, a sprinkler type rainfall simulator (Wilcox et al. 1986) was used to apply rainfall at a rate of $7.62 \mathrm{~cm} \mathrm{hour}^{-1}$ to a $0.5 \mathrm{~m}^{2}, 10 \%$ slope, ungrazed plot located adjacent to the $10 \%$ slope overland flow plot site. This rainfall intensity exceeds the estimated 100 year return period 30 minute duration rainfall event for the site. Rainfall was applied to the plot until equilibrium overland flow had been achieved. At that point four, $200 \mathrm{~g}$ fecal pats dosed with $1 \times 10^{5} C$. parvum oocysts $\mathrm{g}^{-1}$ of feces were added to the plot. All overland flow from the plot was captured for 90 minutes starting immediately prior to and at 10 minute increments following fecal pat deposition. Concentrations of oocysts in the samples were measured for each sample by the same method described above.

\section{Results and Discussion}

Precipitation and stream flow from the 138 ha experimental watershed containing the plots was recorded on a 0.25 hour time

Table 1. Analysis of variance with repeated measures of square root transformed $C$. parvum concentration (No. oocysts liter ${ }^{-1}$ ), with slope as the fixed factor and sample date as the repeated measure.

\begin{tabular}{llcccc}
\hline \hline Source & df & Sum of Squares & Mean Sum of Squares & F & P \\
\hline Mean & 1 & 28971 & 28971 & 28.06 & 0.01 \\
Slope effect & 2 & 21523 & 10762 & 10.42 & 0.04 \\
Error & 3 & 3097 & 1032 & & \\
SampleDate & 3 & 11333 & 3778 & 2.15 & 0.16 \\
Slope x Sample Date & 6 & 16534 & 2756 & 1.57 & 0.26 \\
Error & 9 & 15842 & 1760 & & \\
\hline
\end{tabular}

step (Fig. 1). These data are presented to illustrate the timing and magnitude of the storms experienced during this experiment. Overland flow generated by 4 discrete storm events commencing on 3 February 1996,4 February 1996, 18 February 1996, and 11 March 1996 was composite sampled during the study. The storm commencing 3 March 1996 generated no overland flow from the plots. Composite overland flow samples from the plots were collected at approximately 1500 hours on 4 February 1996, 8 February 1996, 22 February 1996, and 12 March 1996. Total rainfall for the 4 February 1996, 8 February 1996, 22 February 1996, and 12 March 1996 sample periods was 46, 55, 64, and $32 \mathrm{~mm}$ respectively. Following 12 March 1996, no overland flow was realized from the plots for the remainder of the 1995 water year.

Figure 2 illustrates $C$. parvum concentration by slope and sample date. ANOVA with repeated measures (sample date) reveals that while the effect of slope was significant at the 0.05 confidence level, sample date (storm event) and the potential interaction between slope and sample date were not significant (Table 1). Tukey comparison of means reveals that $C$. parvum concentrations are significantly 
Table 2. Mean and standard error for $C$. parvum concentration (No. oocysts liter $\left.{ }^{-1}\right)$ in runoff, stratified by slope and pooled across sample date.

\begin{tabular}{|c|c|c|c|}
\hline & \multicolumn{3}{|c|}{ Slope } \\
\hline & $10 \%$ & $20 \%$ & $30 \%$ \\
\hline & \multicolumn{3}{|c|}{ (No. oocysts liter ${ }^{-1}$ ) } \\
\hline Mean & $112,5^{\mathrm{a}}$ & $2587.5^{\mathrm{ab}}$ & $9462.5^{\mathrm{b}}$ \\
\hline SE Mean & 78.9 & 2432.5 & 3843.6 \\
\hline $\mathrm{n}$ & 8 & 8 & 8 \\
\hline
\end{tabular}

different at the $10 \%$ and $30 \%$ slopes, but that neither the $10 \%$ and $20 \%$ slopes or the $20 \%$ and $30 \%$ slopes are statistically different (Table 2).

Greater concentrations of C. parvum were detected in the runoff with increasing slope. Given the low bulk density, high porosity, and high sand content of the soil type, we would expect high infiltration rates and substantial subsurface flow. For a given soil, the amount of infiltration, and thus overland flow, on a plot is in part a function of slope. Velocity of overland flow increases as slope increases, thus flow has less time and opportunity to infiltrate over a $1.0 \mathrm{~m}$ distance as slope increases. We speculate that the increase in $C$. parvum concentration in runoff as slope increases can be explained by an increase in overland flow volume and a decrease in the filtration efficiency of the buffer strip as slope and runoff volume increases. Under the assumption that a greater volume of water per storm moved across the 1 meter buffer with increasing slope, we hypothesize that the depth of overland flow is nec-

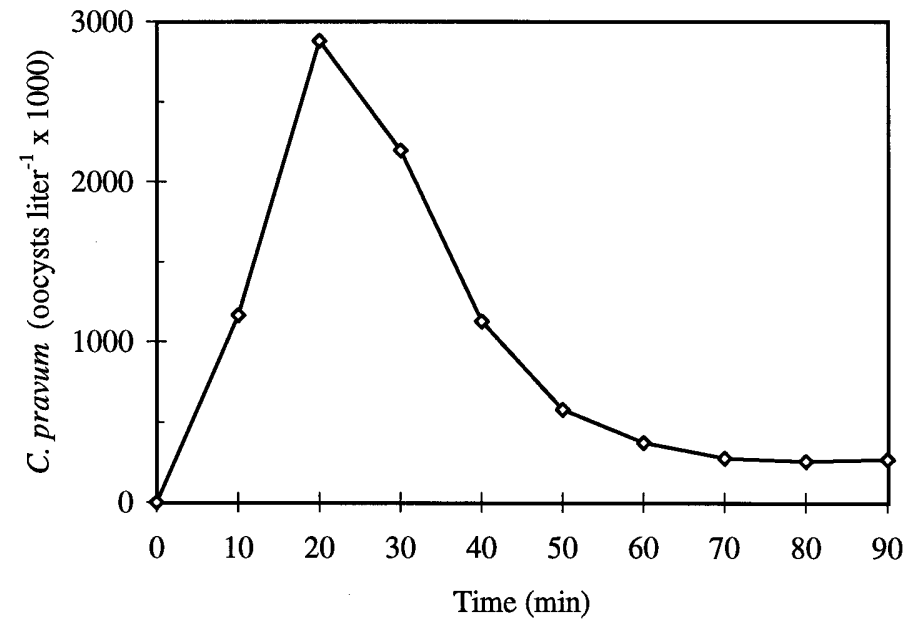

Fig. 3. C. parvum concentration in overland flow sampled $1.0 \mathrm{~m}$ from fecal pats at 10 minute increments during a simulated rainfall trial.

essarily increased, thereby decreasing the filtration efficiency of the buffer strip for removing oocysts suspended in overland flow. In their study of oocyst transport from liquid manure slurry, Mawdsley et al. (1996) observed the greatest overland oocyst transport from soil boxes with the greatest overland flow volume.

Although sample date was not significant, there is a tendency for oocyst concentrations to decline over time (Fig. 2). Concentrations for the 22 February 1996 sample period were much lower than the 4 February 1996 and 8 February 1996 sample period, despite the greater rainfall and total runoff during the 22 February 1996 sample period. This suggests that the

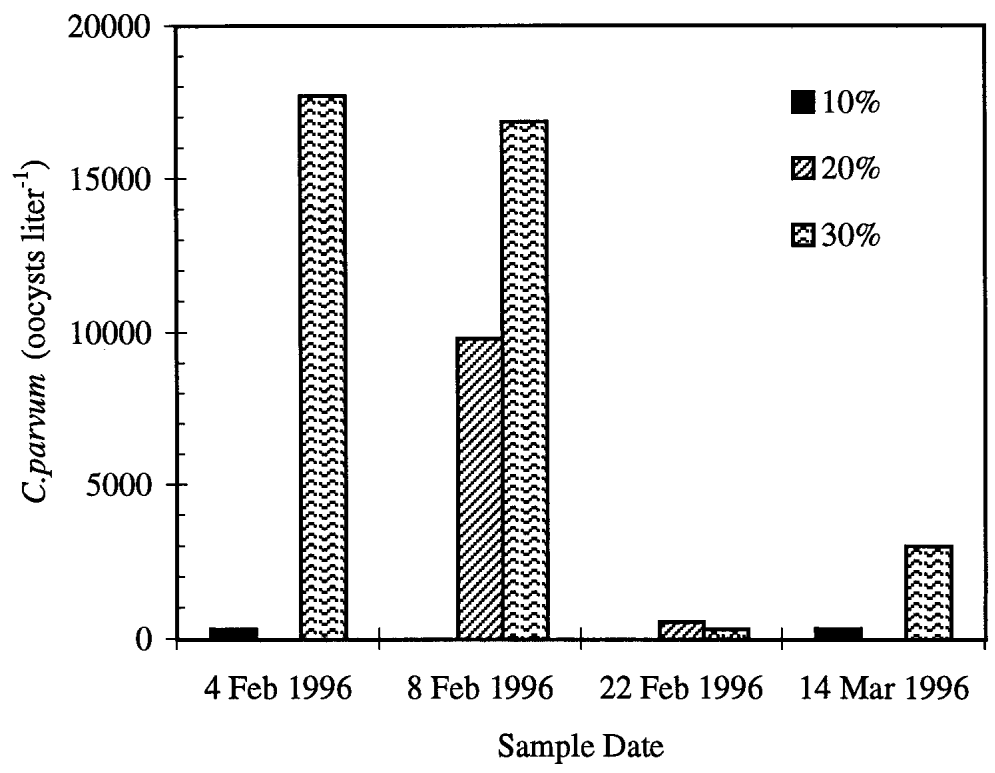

Fig. 2. $C$. parvum concentrations in overland flow sampled $1.0 \mathrm{~m}$ from fecal pats by slope and storm event from the San Joaquin Experimental Range watershed.

majority of oocysts available for overland transport were "flushed" from the fecal pats and the $1.0 \mathrm{~m}$ buffer by the initial storms following fecal deposition on 2 February 1996. Kress and Gifford (1984) observed this same flushing phenomena for fecal coliforms as a function of age of fecal pat and recurrent simulated rainfall. Over their 70 day trial, Mawdsley et al. (1996) reported a steady decline in oocysts in overland flow until day 21. Oocysts in leachate also steadily declined until day 70 .

There was an evident "flushing" of oocysts from the 4 fecal pats and the 0.5 $\mathrm{m}^{2}$ plot during the 90 minute rainfall simulation period (Fig. 3). The majority of the oocysts available for overland transport left the plot early in the simulation, with a tailing effect after 60 minutes. Given that equilibrium overland flow $\left(12 \mathrm{ml} \mathrm{min}^{-1}\right)$ was occurring throughout the experiment, the "flushing" effect is a function of oocyst supply for transport rather than the transport potential, which was constant. This trial also provides insight into the ratio of runoff to subsurface flow on these hillslopes. At a rainfall intensity of 7.62 $\mathrm{cm}$ hour', a 90 minute simulation, and a plot area of $0.5 \mathrm{~min}^{2}, 28.57$ liters of water were applied to the plot but only 1.08 liters of overland flow left the plot. Assuming no loss to interception or evaporation, 27.49 liters $(96 \%)$ of applied rainfall left the plot as subsurface flow. This indicates that leaching of oocysts via subsurface flow is likely the major transport path on these rangelands, and is the next logical hillslope transport process to examine. 


\section{Conclusions}

The hypothesis that $C$. parvum oocysts are not transported at least $1.0 \mathrm{~m}$ as overland flow from fecal deposits with natural rainfall can be rejected. Transport of $C$. parvum oocysts increases as slope increas es, which we hypothesize to be the result of reduced filtration efficiency of the buffer strip subsequent to the larger volume and depth of water moving across the buffer. There is an apparent "flushing" of oocysts by the initial storms following fecal deposition. The rainfall simulation experiment also indicates a "flushing" of oocysts during the first 20 minutes of a storm event. Under the realistic scenario examined in this study, it is clear that $C$. parvum oocysts in fresh fecal pats on rangeland can be released with rainfall and become available for transport to waterbodies. Overland, as well as vertical and lateral subsurface, transport of oocysts on rangeland hillslopes needs further examination at distances greater than $1 \mathrm{~m}$ and on a variety of soil types. This information will be important in assessing the potential for buffer strips to prevent surface water contamination with this parasite from bovine and other fecal sources.

It is also important to note that in order for these bovine-derived oocysts to become a public health threat, oocysts have to be transported out of fecal pats, and they need to remain infective while being transported to a susceptible host. Environmental conditions on rangeland, such as heating, freezing, or drying, can rapidly inactivate large numbers of oocysts (Walker et al. 1998), but only a few oocysts would need to remain infective in order to pose a risk to humans. The illness can be fatal to persons with compromised immune systems. Experimental studies in healthy humans determined that as few as 30 bovine-derived oocysts were capable of initiating cryptosporidiosis in humans (DuPont al. 1995). Addressing the potential for $C$. parvum in cattle fecal deposits on rangeland watersheds to threaten human health will require sitespecific examination of the sources in the watershed (Atwill et al. 1999), viability of oocysts under harsh rangeland conditions (Walker et al. 1998), hydrologic transport of oocysts within the watershed, and the spatial and temporal distribution of fecal material in relation to surface water bodies (Tate et al. 1998).

\section{Literature Cited}

Arrowood, M. J. and C. R. Sterling. 1987. Isolation of Cryptosporidium parvum and sporozoites using discontinuous sucrose and isopycnic Percoll gradients. J. Parasitol. 73:314-319.

Atwill, E.R., E. Johnson, D.J. Klingborg, G.M. Veserat, G. Markegard, H.A. Jensen, D.W. Pratt, R.E. Delmas, HA. George, L.C. Forero, R.L. Phillips, A.O. Nelson, S.J. Barry, N.K. McDougald, R.R Gildersleeve, and W.E. Frost. 1999. Age, geographic, and temporal distribution of fecal shedding of Cryptosporidium parvum oocysts in cow-calf herds. Amer. J. Vet. Res. 60:420-425.

Barry, S.J., E.R. Atwill, K.W. Tate, T.S. Koopmann, J. Cullor, and T. Huff. 1998. Developing and implementing a HACCP-based program to control Cryptosporidium and other waterborne pathogens in Alameda Creek Watershed: a case study. Proc. of Amer. Water Works Assoc. Ann. Conf Dallas, Tex. (In press.)

Buckouse, J.C. and G.F. Gifford. 1976. Water quality implications of cattle grazing on a semiarid watershed in southeast Utah. J. Range Manage. 29:109-113.

Casemore, D.P., S.E. Wright, and R.L. Coop. 1997. Cryptosporidiosis-human and animal epidemiology. p. 65-92. In: Cryptosporidium and Cryptosporidiosis. CRC Press, Inc. Boca Raton, Fla.

Dixon, W.J. 1992. BMDP Statistical software manual. University of California Press. Berkeley, Calif. 678 pp.

DuPont, H.L., C. L. Chappell, C. R. Sterling, P. C. Okhuysen, J. B. Rose, and W. Jakubowski. 1995. The infectivity of Cryptosporidium parvum in healthy volunteers. New England J. Medicine. 332:855-859.

Fayer, R., L. Gasbarre, P. Pasquali, A. Canals, S. Almeria, and D. Zarlenga. 1998. Cryptosporidium parvum infection in bovine neaonates: dynamic clinical, parasitic and immunologic patterns. Internat. J. Parasitology. 28:49-56.

Gary, H.L., S.R. Johnson, and S.L. Ponce. 1983. Cattle grazing impact on surface water quality in a Colorado front range stream. J. Soil and Water Conser. 38:124-128.

Haan, C.T., B.J. Barfield, and J.C. Hayes. 1994. Design hydrology and sedimentology for small catchments. Academic Press. 588 pp.

Hafez, E.S.C. 1969. The behavior of domestic animals. Williams and Wilkins Co. Baltimore, Md. 647 pp.

Kress, M. and G.F. Gifford. 1984. Fecal coliform release from cattle fecal deposits. Water Res. Bull. 20:61-66.

Larsen, R.E. 1989. Water quality impacts of free ranging cattle in semi-arid environments. M.S. Thesis, Oregon State Univ. Corvallis, Ore. pp. 92
Larsen, R.E., JR. Miner, J.C. Buckhouse, and J.A. Moore. 1994. Water quality benefits of having cattle manure deposited away from streams. Biores. Tech. 48:113-118.

Larsen, R.E., J.C. Buckhouse, J.A. Moore and J.R. Miner. 1988. Rangeland cattle and manure placement: a link to water quality. Oregon Acad. of Sci. 24:7-15.

LeChevallier, M.W. and W.D. Norton. 1995. Giardia and Cryptosporidium in raw and finished water. Amer. Water Works Assoc. 87:54-68.

MacKenzie, W.R., N.J. Hoxie, M.E. Proctor, M.S. Gradus, K.A. Blair, D.E. Peterson, J.J. Kazmierczak, D.G. Addiss, K.R. Fox, J.B. Rose, and J.P. Davis. 1994. A massive outbreak in Milwaukee of Cryptosporidium infection transmitted through the public water supply. New England J. Medicine 331:161-167.

Mawdsley, J.L., A.E. Brooks, R.J. Perry, and B.F. Pain. 1996. Use of a novel soil tilting table apparatus to demonstrate the horizontal and vertical movement of the protozoan pathogen Cryptosporidium parvum in soil. Biol, Fertil. Soil. 23:215-220.

Stephens, T. 1997. San Francisco water district targets cattle. California Agr. 51:7.

Tate, K.W., N.K. McDougald, ER. Atwill, M.R. George, and D. Wiff. 1998. A Rapid Method for Estimating Livestock Manure Deposition on Rangeland Watersheds. p. 135. In: Specialty Conference on Rangeland Management and Water Resources. Amer. Water Res. Assoc

Thelin, R. and G.F. Gifford. 1983. Fecal coliform release patterns from fecal material of cattle. J. Environ. Qual. 12:57-63.

Tyzzer, E.E. 1912. Cryptosporidium parvum (sp. nov.), a coccidian found in the small intestine of the common mouse. Archivfur Protistenkunde. 26:394-412.

Walker, M.J., C.D. Montemagno, and M.B. Jenkins. 1998. Source water assessment and nonpoint sources of acutely toxic contaminants: a review of research related to the survival and transport of Cryptosporidium parvum. Water Resour Res. 34:3383-3392.

Wilcox, B.P., M.K. Wood, J.T. Tromble, and T.J. Ward. 1986. A hand-portable single nozzle rainfall simulator designed for use on steep slopes. J. Range Manage. 39:375-377.

Xiao, L. and R.P. Herd. 1994. Infection patterns of Cryptosporidium and Giardia in calves. Veterinary Parasitology. 55:257-262. 